\title{
THE INFLUENCE OF ANTI-HIV-1 SPECIFIC IgY IN INHIBITING HIV-1 INFECTION IN BINDING PHASE WITH SYNCYTIUM EXAMINATION OF CD4 RECEPTOR DENSITY USING THE FLOWCYTOMETRY METHOD
}

\author{
Wiwiek Indriyani Maskoep ${ }^{1}$, Nasronudin ${ }^{2}$, Siti Khairunisa ${ }^{3}$, Sri Agus Sudjarwo ${ }^{4}$ \\ ${ }^{1}$ Doctoral Study Program, Faculty of Medicine, Universitas Airlangga, Surabaya, ${ }^{2}$ Universitas Airlangga Hospital, \\ Surabaya, ${ }^{3}$ Institute of Tropical Disease, ${ }^{4}$ Faculty of Veterinary, Universitas Airlangga, Surabaya, Indonesia
}

\section{ABSTRACT}

\begin{abstract}
HIV/AIDS infections have increased and spread very quickly in the world, including in Indonesia. The absence of an effective vaccine and the fact that antiretroviral drugs can only suppress the progression of infection but cannot eradicate it lead to the efforts to find materials containing immunoglobulins that can replace the immune system which greatly declines in HIV/ AIDS patients. The successful use of specific IgY in other studies opens up opportunities for the use of anti-HIV-1 specific IgY as passive immunotherapy. This type of research is true experimental research design with post-test only control group design. IgY was obtained from Lohmann Laying hens chicken eggs immunized with the inactivated HIV-1 virus. The concentration of IgY was determined using the Bradford method and then the characterization test was continued using the AGPT, ELISA, SDS$P A G E$ and Western blot tests which showed anti-HIV-1 specific IgY. The results of the test showed specific anti-HIV-1 IgY was effective in inhibiting the formation of syncytium in HIV-1 infection against CD4+T lymphocytes in the binding phase (entry stage) in the treatment group p-value $0.000(p<0.05)$. The results of CD4 receptor density tests using the Flowcytometry method showed that specific anti-HIV-1 IgY was effective in inhibiting HIV-1 infection against CD4+ Tlymphocytes in the binding phase (entry stage) in the treatment group p-value $0.047(p<0.05)$.
\end{abstract}

Keywords: Anti-HIV-1 Specific IgY; HIV-1; Syncytium and CD4 receptor

\section{ABSTRAK}

\begin{abstract}
Infeksi HIVIAIDS meningkat dan menyebar sangat cepat di dunia, termasuk di Indonesia. Tidak adanya vaksin yang efektif dan fakta bahwa obat antiretroviral hanya dapat menekan perkembangan infeksi tetapi tidak dapat memberantasnya mengarah pada upaya untuk menemukan bahan yang mengandung imunoglobulin yang dapat menggantikan sistem kekebalan yang sangat menurun pada pasien HIVIAIDS. Keberhasilan penggunaan IgY spesifik dalam penelitian lain membuka peluang untuk penggunaan IgY spesifik anti-HIV-1 sebagai imunoterapi pasif. Jenis penelitian yang digunakan adalah true experimental research design dengan post-test only control group design. IgY diperoleh dari telur ayam ras Lohmann yang diimunisasi dengan virus HIV-1 yang telah dilemahkan. Kadar IgY ditentukan dengan metode Bradford kemudian uji karakterisasi dilanjutkan dengan uji AGPT, ELISA, SDS-PAGE dan Western blot yang menunjukkan IgY spesifik anti HIV-1. Hasil tes menunjukkan anti HIV spesifik IgY efektif menghambat pembentukan syncytium pada infeksi HIV-1 melawan CD4 + T limfosit pada fase pengikatan (entry stage) pada kelompok perlakuan p-value 0,000 ( $p<0,05)$.). Hasil tes kepadatan reseptor CD4 menggunakan metode Flowcytometry menunjukkan bahwa anti HIV spesifik IgY efektif dalam menghambat infeksi HIV-1 terhadap CD4 + T limfosit pada fase pengikatan (entry stage) pada kelompok perlakuan nilai p 0,047 $(p<0,05)$.
\end{abstract}

Kata kunci: IgY Spesifik Anti HIV-1; HIV-1; Syncytium dan reseptor CD4

Correspondence: Wiwiek Indriyani Maskoep, Perumahan Wisma Permai Barat I Blok MM No.40 Surabaya. Phone: (031) 5501089/(031) 5018840. Fax: (031) 5018840. E-mail: wiwiekindriyani@yahoo.co.id

pISSN:2355-8393 • eISSN: 2599-056x • doi: http://dx.doi.org/10.20473/fmi.v56i4.23414

- Fol Med Indones. 2020;56:290-295 • Received 4 Oct 2019 • Accepted 9 Apr 2020

- Open access under CC-BY-NC-SA license • Available at https://e-journal.unair.ac.id/FMI/

\section{INTRODUCTION}

There are 2 subtypes of HIV, namely HIV-1 (spreading worldwide) and HIV-2 (spreading in West Africa). In patients, HIV infection goes through four phases, namely acute, asymptomatic or latent phases, AIDS related complex (ARC) and Acquired Immune Deficiency Syndrome (AIDS). And, HIV-1 is a cytopathic virus classified in the family retroviridae, subfamily lentivirinae, genus lentivirus. HIV/AIDS infection can affect anyone with a means of transmission mainly through sexual contact, narcotics, 
psychotropic and injectable addictive substances, blood transfusions and infections from mother to fetus. The HIV virus enters the body infecting cells that have the Cluster of Differentiation $4(\mathrm{CD} 4+)$ protein molecule (Kindt et al 2007, Levinson, 2014, Merati 2014).

Every year cases of HIV/ AIDS have increased. In 2017 the number of HIV/AIDS cases in the world was 36.9 million, an increase compared to 2016 (36.7 million) (WHO, 2017, 2018). In Indonesia the region with the highest number of HIV infections was DKI Jakarta $(55,099)$, followed by Java East $(43,399)$, West Java (31,293), Papua $(30,699)$ and Central Java $(24,757)$ (DITJEN PP\&PL, Dinas Kesehatan Provinsi Jawa Timur 2017).

The high number of HIV/ AIDS cases in Indonesia means a problem that must get concern from various parties, especially those in the medical field to give their real contribution both preventively and curatively in the response to HIV/ AIDS. The fact that vaccines for HIV haven not been found and antiretroviral drugs that have been developed very fast growing recently are still at a level capable of suppressing the progression of the disease but have not been able to eradicate the HIV virus, substitution therapy is needed to replace the declining immune system using immunotherapy. The successful use of IgY as a specific immunoglobulin in other studies opens the opportunity for success in the application of using IgY as an anti-HIV-1 specific antibody (Nguyen et al 2010, Rahman et al 2013, Wen et al 2012, Thu et al 2017).

This study used syncytium formation and Flowcytometry tests to measure the density of CD4 receptors, so it could be known whether anti-HIV-1 specific IgY is effective in inhibiting HIV-1 infection against $\mathrm{CD} 4+\mathrm{T}$ lymphocytes in the binding phase (entry stage) in the treatment group.

\section{MATERIALS AND METHODS}

\section{Preparation of virus antigens}

Sample of blood from HIV-1 patients was taken as much as $13 \mathrm{~mL}$ through a cubital vein for the making of vaccines and virus stocks then kept it in a vacutainer containing EDTA anti-coagulant, centrifuging the blood at $2000 \mathrm{rpm}$ for 10 minutes. The plasma containing virus was collected and then activated using formaldehyde $1 \%(\mathrm{v} / \mathrm{v})$ at $4^{\circ} \mathrm{C}$ for 5 days, then the virus that had been inactivated was injected intramuscularly into the body of a Lohmann laying hens chicken as an experimental animal.

\section{Immunization of chicken with HIV-1 Virus and IgY characterization}

Lohmann Laying chickens were intramuscularly immunized with the HIV-1 virus which has been inactivated using $1 \%(\mathrm{v} / \mathrm{v})$ formaldehyde at $32 \mathrm{oC}$ for 5 days with a dose of $80 \mathrm{CE}^{\circ} \mathrm{g}$ and mixed with $0.25 \mathrm{CE}^{\circ} \mathrm{L}$ of Freund's Complete Adjuvant (FCA). Immunizations were repeated twice at two-week intervals with a dose of $80 \mu \mathrm{L}$ and mixed with $0.25 \mu \mathrm{L}$ Incomplete Freund's Adjuvant (IFA). Then purification is done using the PEG 6000 precipitation method. The concentration of the purified IgY was determined by Bradford method. Then IgY was characterized using AGPT, ELISA, SDSPAGE and Western blot test which showed that the IgY tested was anti-HIV-1 specific IgY, then stored at $20^{\circ} \mathrm{C}$.

\section{Syncytium formation test}

Syncytium formation test begins by measuring the MOLT 4 cells. If there are 106 cells $/ 50 \mathrm{EE}^{\circ} \mathrm{L}$, then it can be used. Then HIV-1/MT4 cells are measured, and, if there are 105 cells $/ 50 \mathrm{E}^{\circ} \mathrm{L}$, then the neutralization activity test is ready to be done. Next, antibodies ( $\operatorname{IgY}$ ) are dissolved with RPMI media according to the desired concentration, that is, the concentration obtained from the results of the Bradford test characterization by the spectrophotometer method, and a preliminary (optimization) test is carried out until the $\operatorname{IgY}$ concentration obtained does not cause cell death. The next step is putting $100 \mu \mathrm{L}$ RPMI in all wells both control and treatment groups, putting $200 \mu \mathrm{L} \operatorname{IgY}$ in the first row of wells continued with outing $100 \mu \mathrm{L}$ RPMI in wells in the first, second and so on up to the 8th rows, then making a serial dilution by taking $100 \mathrm{CE}^{\circ} \mathrm{L}$ from the first row and adding it to the second row, then pipetting it taking $100 \mu \mathrm{L}$ from the second row and adding it to the third row. The process is repeated until it goes to the 8th row, so the concentration obtained reaches half of the previous concentration. The next step is putting $50 \mu \mathrm{L}$ of HIV-1/MT4 cells into each of the wells in a plate already containing IgY. The plates were then incubated for 30 minutes in $\mathrm{CO} 2$ incubators (to see whether IgY and HIV-1/MT4 cells were bound or not) and then put $50 \mu \mathrm{L}$ MOLT4 cells into each well in a plate containing IgY and incubated in $\mathrm{CO} 2$ incubators for 24 hours. At the same time, the same process was done but without the administration of $\operatorname{IgY}$ as a control group. Syncytium measurement was done from the results formed under a microscope thus evaluating the anti-syncytium forming activity of anti-HIV-1 specific IgY. At the same time the same process was done to the group without treatment. Culture fluids from the results of the syncytium formation test can be used to analyze the density of CD4 receptors. 


\section{CD4 receptor density using the flowcytometry method}

In preparing the sample for the flowcytometry test it began by preparing 1 conicle for 1 type of treatment, then labelling the conicles in each treatment group, taking a culture fluid (the results of the anti-HIV-1 specific IgY activity test using the Syncytium formation test method) and then pipetting it. The culture liquid was then centrifuged at $1500 \mathrm{rpm}$ for 5 minutes, the supernatant was kept in a freezer at $-800 \mathrm{C}$, whereas the pellet was used for the flowcytometry test. Cell pellets were washed with staining buffer cells 1 time and then centrifuged at $2500 \mathrm{rpm}$ for 3 minutes at $40 \mathrm{C}$.

The supernatant was removed and the cell pellets formed were ready for staining with CD4 surface marker cell antibodies $(5 \mu \mathrm{L}$ per sample 1:10 diluted in staining buffer cells). The diluted antibodies were then taken as much as $50 \mu \mathrm{L}$ and mixed with cell pellets and homogenized. Cell pellets that had been given antibodies were incubated for 20 minutes in the dark at room temperature. After incubation the cell pellets were then added with $500 \mu \mathrm{L}$ staining buffer cells, the addition of staining buffer cells at this stage was a buffer without surface marker antibodies (buffer only). This stage aims to color the target bound by the marker, and then homogenized again then transferred to the cuvette and then measured with flowcytometer.

\section{Research method}

This was true experimental research to prove the antiHIV-1 specific IgY neutralization activity with the syncytium formation test method and the examination of CD4 receptor density using the Flowcytometry method. The study used a post-test only control group design.

\section{Technique of statistical analysis}

The data obtained was then analyzed descriptively and inferentially. Data analyzed descriptively were used to determine the mean values of syncytium formation and CD4 receptor density, while the inferential analysis used were $\mathrm{t}$ and ANOVA Kruskal Wallis tests using the SPSS 21 application.

\section{RESULTS}

\section{Syncytium formation test}

Based on syncytium formation test for the group added with anti-HIV-1 specific IgY (as a treatment group) and the group not added with anti-HIV-1 specific IgY (as a control group) at the 24-hour observation, the number of syncytium formed turned to be more in the control group (28.95) than that in the treatment group (14.9) with $\mathrm{p}$-value of $0.000(\mathrm{p}<0.05)$, meaning there were significant differences (there was a significant effect) of giving anti-HIV-1 specific IgY to the formation of Syncytium (Table 1).

CD4 receptor density test using the flowcytometry method

The average percentage of CD4 receptor density formed in the control group was smaller (9.96) than that in the treatment group (11.8) with a p-value of $0.047(\mathrm{p}<0.05)$, so that it could be concluded that administration of antiHIV-1 specific IgY was effective in inhibiting HIV-1 infection in CD4+ $\mathrm{T}$ lymphocytes in the binding phase (entry stage) in the treatment group at 24-hour observation (Table 2).

Table 1. Frequency distribution of formation of Syncytium in the treatment and control groups

\begin{tabular}{lccccc}
\hline \multirow{2}{*}{ Group } & \multicolumn{5}{c}{24 hours } \\
\cline { 2 - 6 } & $\mathrm{N}$ & Mean & Minimum & Maximum & $\mathrm{p}$-value \\
\hline Control & 40 & 28.9 & 10 & 82 & 0.000 \\
Treatment & 40 & 14.9 & 4 & 45 & \\
\hline
\end{tabular}

Table 2. Frequency distribution of CD4 receptor density in the treatment and control groups

\begin{tabular}{lccccc}
\hline Group & \multicolumn{5}{c}{24 hours } \\
\cline { 2 - 5 } & $\mathrm{N}$ & Mean & Minimum & Maximum & p-value \\
\hline Control & 5 & 9.69 & 8.65 & 12.502 & 0.047 \\
Treatment & 5 & 11.8 & 10.70 & 13.08 & \\
\hline
\end{tabular}



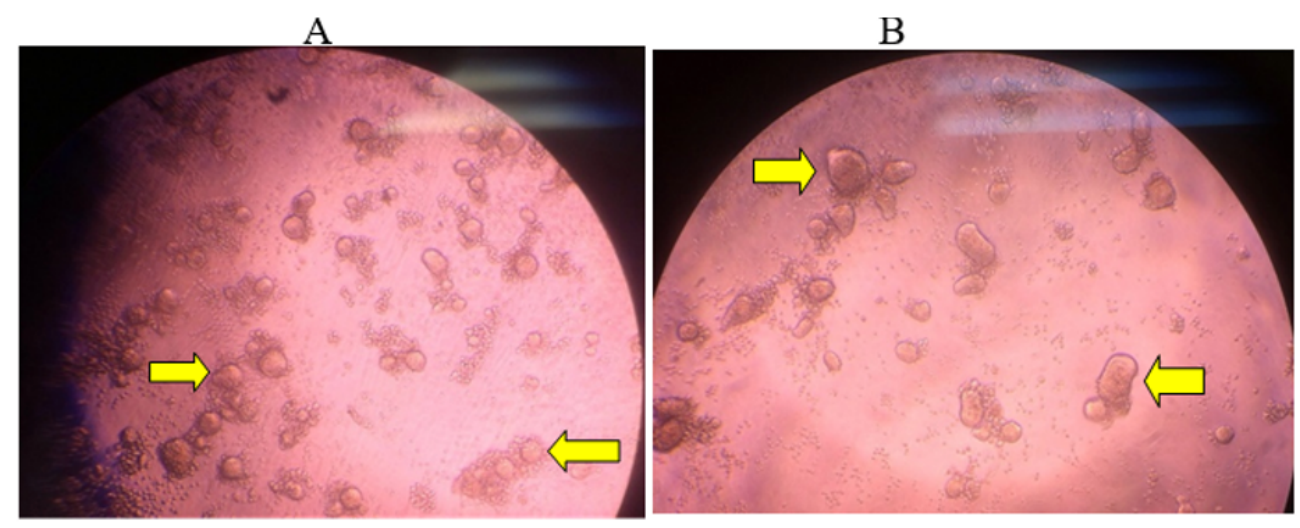

Fig. 1. Syncytium test in control group at 24 hours observation (A); Syncytium test in treatment group at 24 hours observation (B).

\section{DISCUSSION}

The advantages of using IgY rather than mammalian IgG are that because IgY is: 1). not toxic, because eggs are common daily food consumed, 2) Non allergic, as allergic reactions generally occur due to consuming large amounts of egg whites, but IgY is soluble in water purified from egg yolks (without lipids) and it usually does not cause allergies, 3) No serological cross reactivity, i.e. $\operatorname{IgY}$ does not react with rheumafactors because the FC epitopes (factor of crystallin) of IgY are not recognized by the antibody binding site of rheumafactor, IgY does not activate mammalian complement, and $\operatorname{IgY}$ is a functional analog with mammalian IgGs so it does not cause effects beside serum sickness and shock anaphylactic, and 4) Effective alternative to antibiotics: for example, IgY can be an alternative treatment for antibiotic resistance to enteral pathogens, because it has been proven that $\operatorname{IgY}$ can prevent interactions between microorganisms and target cells. Therefore, the use of IgY as an anti-HIV-1 specific antibody may be applied (Larsson et al 1991, Larsson et al 1992, Warr et al 1995, Carlander 2002, Mine \& Kovacs-Nolan 2002, Karlsson et al 2004, Schade et al 2005, Wang et al 2011, Rahman et al 2013, Zoerriehzahra et al 2016).

The results of the syncytium formation test showed that anti-HIV-1 specific IgY was effective in inhibiting the formation of Syncytium in HIV-1 infection against CD4+ T lymphocytes in the binding phase (entry stage) at 24-hour observation ( $p<0.05$ HIV-1 can induce the formation of syncytium which is a multinucleus protoplasmic mass formed by combining a number of cells so that the syncytium size can be more than 4 to 100 times than that of a single cell. Syncytium of medium size translocates itself through the extension of giant pseudopods. Single cell motility, syncytium motility, and extension of pseudopod play a role in the entry of cells into syncytium. Compaction of F-actin in the adhesion area between cells with syncytium and syncytium with syncytium suggested that the cytoskeleton was involved in the event of adhesion or subsequent fusion. This suggested that fusion events were involved in the formation of syncytium by induction of HIV-1, involving both motility and reorganization of the cytoskeleton (Sylwester et al 1993, Watkins et al 1997).

The results of density test of the CD4 receptor using Flowcytometry method at 24-hour observation showed that anti-HIV-1 specific IgY was effective in inhibiting HIV-1 infection against T CD4+ lymphocytes in the Binding Phase (Entry stage) in the treatment group ( $p$ $<0,05)$. The results of this study supported by Delves et al (2011) stating that the first time the HIV-1 virus infected CD4+ $\mathrm{T}$ lymphocytes mediated by spike interactions (which are sharply rising deflections) of the gp120 envelope on the surface of the virus with CD4 receptors on the surface of $\mathrm{T}$ lymphocytes $\mathrm{CD} 4+$, but with the provision of anti-HIV-1 specific IgY, the antibody molecule would approach the spike and bind to it, so that no HIV-1 infection process would occur. This process is a function of the neutralizing antibody ability (inhibits the ability of the virus to infect by inhibiting viral attachment, penetration, or the release of viral envelopes, or all three processes at once). These neutralization antibody processes depend on: the number of glycoprotein molecules (spikes) from the envelope surface which are generally around 7 to 14 envelope knops per virion, but the amount can vary, the ability of antibodies to cover and shed/release envelope protein gp120 from virion (Shedding), all envelope proteins in the virion must be targeted by at least one antibody to get enough neutralization, and the ability of 
antibodies to penetrate hidden CD4 binding sites at gp120 (Levy 2007).

\section{CONCLUSION}

Anti-HIV-1 specific IgY is effective in inhibiting the syncytium formation in HIV-1 infection against CD4+ $\mathrm{T}$ lymphocytes in the binding phase (entry stage) in the treatment group. The results of the examination of CD4 receptor density using Flowcytometry method showed that anti-HIV-1 specific IgY is effective in inhibiting HIV-1 infection of CD4+ T lymphocytes in the binding phase (entry stage) in the treatment group.

\section{ACKNOWLEDGMENT}

This research was supported by the Faculty of Medicine, Universitas Airlangga and Institute Tropical Disease (ITD).

\section{REFERENCES}

Carlander, D (2002). Avian IgY antibody in vitro and in vivo. Master Dissertation. Acta Universitatis Upsaliensis. Uppsala. pp. 433-437. Available at: http://www.divaportal.org/smash/get/diva2:161296/FULLTEXT01.p df\&gt;. Accessed January 24, 2009

Delves P, Martin S, Burton D, Roitt I (2011). Roitt's Essential Immunology: chapter 14immunodeficiency. 12th Ed. UK, John wiley \& Sons, p 369-393

DITJEN PP\&PL Dinas Kesehatan Provinsi Jawa Timur (2017). Laporan Tahunan Program HIV-1/AIDS di Provinsi Jawa Timur. Dinas Kesehatan Provinsi Jawa Timur. Surabaya. Pp.5-22. Available at: http://www.depkes.go.id/resources/download/profil/ PROFIL_KES_PROVINSI_2017/15_Jatim_2017.pd f. Accessed March 25, 2018

Levinson W (2014). Review of medical microbiology and immunology: part III-basic virology. 13th Ed. US, Mc Graw Hill Education, p 220-278

Karlsson M, Kollberg H, Larsson A (2004). Chicken IgY: utilizing the evolutionary advantage. World's Poultry Science Journal 60, 341-348. Available at: https://www.sciencedirect.com/science/article/pii/01 4795719090088B?via\%3Dihub. Accessed July, 28 2015

Kindt TJ, Osborne BA, Goldsby RA (2007). Kuby Immunology. 6th Ed: chapter 19-AIDS and Other Immunodeficiencies. New York, W.H. Freeman and Company, p 431-461.
Larsson A, Karlsson-Parra A, Sjoquist J (1991). Use of chicken antibodies in enzyme immunoassays to avoid interference by rheumatoid factors. Clinical Chemistry 37, 411-414. Available at: http://clinchem.aaccjnls.org/content/clinchem/37/3/4 11.full.pdf. Accessed September 22, 2015

Larsson A, Wejker P, Forsberg P, Lindahl T (1992). Chicken antibodies: a tool to avoid interference by complement activation in ELISA. Journal of Immunological Methods 156, 79-83. Available at: https://www.sciencedirect.com/science/article/pii/00 2217599290013J?via\%3Dihub. Accessed July 14, 2016

Levy JA (2007). Discovery, structure, heterogeneity, and origins of HIV-1: chapter 6- Cytopathic Properties of HIV. In: Buku Ajar Ilmu Penyakit Dalam. Jilid I. Jakarta, Balai Penerbit FK UI, p 133148

Merati T (2014). Acquired Immune Deficiency Syndrome (AIDS). In: Buku Ajar Ilmu Penyakit Dalam, Jilid I. Jakarta, Balai Penerbit FK UI, p 920

Mine Y, Kovacs-Nolan J (2002). Chicken egg yolk antibodies as therapeutics in enteric infectious disease: a review. Journal of Medicinal Food 5, 159169. Available at: http://scihub.tw/https://doi.org/10.1089/10966200260398198. Accessed July 12, 2015

Nguyen H, Tumpey T, Park H, Byun Y, Tran L, Nguyen V, Kilgore P, Czerkinsky C, Katz J, Seong B, et al (2010). Prophylactic and therapeutic efficacy of avian antibodies against influenza virus $\mathrm{H} 5 \mathrm{~N} 1$ and H1N1 in mice. PLoS ONE 5, e10152

Rahman S, Nguyen SV, Umeda K, Kodama Y, Jr. Faustino C (2013). Oral Passive IgY-Based immunotherapeutics a novel solution for prevention and treatment of alimentary tract disease. Human Vaccine \& Immunotherapeutics 09, 1039-1048.

Schade R, Calzado EG, Sarmiento R, Chcana PA, Porankiewicz-Asplund J, Terzolo HR (2005). Chicken Egg Yolk Antibodies (IgY Technology): a review of progress in production and use in research and human and veterinary medicine. Alternatives to laboratory animals 33, 129-154

Sylwester A, Wessels D, Anderson SA, Warren RQ, Shutt DC, Kennedy RC, Soll DR (1993). HIV-1induced syncytia of a $\mathrm{T}$ cell line form single giant pseudopods and are motile. Journal of Cell Science 106, 941-953

Thu, Hlaing Myat, Theingi Win Myat, Mo Mo Win, Kyaw Zin Thant, Shofiqur Rahman, Kouji Umeda, Sa Van Nguyen,Faustino C. Icatlo, Jr., Kyoko HigoMoriguchi, Koki Taniguchi, Takao Tsuji, Keiji Oguma, Sang Jong Kim, Hyun Suk Bae, and Hyuk Joon Choi (2017). Chicken Egg Yolk Antibodies ( $\operatorname{IgY}$ ) for Prophylaxis and Treatment of Rotavirus Diarrhea in Human and Animal Neonates: A 
Concise Review. Korean Journal for Food Science of Animal Resources, 1-9

Wang L, Li, X, Jin L, You J, Zhou Y, Li S, Xu Y (2011). Characterization of chicken egg yolk immunoglobulins (IgYs) specific for the most prevalent capsular serotypes of mastitis-causing Staphylococcus aureus. Veterinary Microbiology. $149,415-421$

Warr G, Magor K, Higgins D (1995). IgY: clues to the origins of modern antibodies. Immunology Today 16, p 392-398

Watkins B, Louie A, Crowley R, Reitz M, Davis A (1997). Syncytium formation induced by human immunodeficiency virus type 1 isolates correlates with affinity for CD4. Journal of General Virology 78, 2513-2522.

Wen J, Zhao S, He D, et al (2012). Preparation and characterization of egg yolk immunoglobulin Y specific to influenza B virus. Antiviral Research. 93, 154-159

Zoerriehzahra MJ, Tiwari R, Sachan S, et al (2016). Avian egg yolk antibodies (IgY) and their potential therapeutic application for countering infectious diseases of fish and aquatic animal. International Journal of Pharmacology 12, 760-768 